\title{
Use of artificial neural network for generation of ultra-high resolution meteorological fields over Chowkibal-Tangdhar region of North-West Himalaya
}

Jagdish Chandra Joshi ( $\sim$ joshjagdih@gmail.com )

Defence Geoinformatics Research Establishment

Prabhjot Kaur

\section{Research Article}

Keywords: Weather prediction, Post-processing, Spatial interpolation

Posted Date: March 2nd, 2022

DOI: https://doi.org/10.21203/rs.3.rs-1339694/v1

License: (c) (i) This work is licensed under a Creative Commons Attribution 4.0 International License.

Read Full License 
2 Use of artificial neural network for generation of ultra-high resolution (9) meteorological fields over Chowkibal-Tangdhar region of North-West Himalaya Authors
Jagdish Chandra Joshi* and Prabhjot Kaur Affiliation Defence Geoinformatics Research Establishment (DGRE), Chandigarh, India

\section{*Corresponding Author's name and address}

Jagdish Chandra Joshi

Defence Geoinformatics Research Establishment

Him Parisar, Sector 37-A

Chandigarh-160036

E-mail: joshjagdish@gmail.com 


\section{Abstract}

High resolution meteorological fields have been found potentially useful for hydrological and agricultural applications and mitigation of hydro-meteorological hazards such as landslide and snow avalanches. These meteorological fields are being generated for Himalaya using Weather Research and Forecast (WRF) model with spatial resolution up to $3 \mathrm{~km}$. However, gridded meteorological data of sub-kilometer resolution is not available for the Himalayan region. In the present study, Numerical Weather Prediction model-WRF has been configured for NorthWest (N-W) Himalayan region with spatial resolution of $2 \mathrm{~km}$ and run in hind cast mode to generate meteorological data of 11 winters (2009-19). Artificial neural networks (ANNs) have been developed for post-processing of maximum temperature, minimum temperature, wind speed, relative humidity, snow depth and snowfall in $24 \mathrm{~h}$ generated by the WRF model using observed surface weather data of five different locations in Chowkibal-Tangdhar (C-T) region. Post-processed WRF output has been spatially interpolated to a grid resolution of $90 \mathrm{~m}$ using quasi-physical relations and inverse distance weighing scheme. The ultra-high resolution meteorological fields generated over the C-T domain have been validated at five locations in the C-T region for two winters (2017-19). For all five stations, the Nash-Sutcliffe Efficiency (NSE) scores of the model for maximum and minimum temperature, relative humidity and snow depth has been found at "very good" level (> 0.75) with considerably high Heidke Skill Score (HSS) (> 0.4). A comparison of observed and simulated cumulative snowfall during major snow storms during 2017-19 has also been discussed.

Keywords: Weather prediction, Post-processing, Spatial interpolation 


\section{Introduction}

High resolution weather data is of prime importance for distributed hydrological modeling studies for water resource management related to agricultural water supply, ecosystem services and hydropower production (Sen Gupta and Tarboton 2013). It is vital for hydrometeorological applications and prediction of associated geo-hazards with high spatial and temporal resolution. In mountainous regions, there is observed large spatial and temporal variability of weather variables which increases with shorter time scales (Krahenmann and Ahrens 2010). Among weather variables, maximum and minimum temperature are valuable inputs for environmental models for simulation of physical processes such as snow melt (Hock 2003). Spatial distribution of rain and snowfall is crucial for planning tasks concerned with water resources, water power, agriculture, glaciology and natural hazards (Holzkämper et al. 2012; Machguth et al. 2009). Simulation of accurate wind field is an important and essential input in aviation and power sectors. In mountainous regions, due to wind re-distributed snow there is accumulation and melt differences leading to large spatial variability of snow cover (Elder et al. 1991; Doesken and Judson 1996; Luce et al. 1998; Balk and Elder 2000) that affects snowmelt runoff patterns and triggering of snow avalanches. The heterogeneity in snow accumulation is largely a function of wind redistribution (Elder et al. 1991; Blöschl and Kirnbauer 1992; Luce et al. 1998; Prasad et al. 2001), whereas snowmelt is affected by spatially varying temperature/energy flux (Elder et al. 1991; Marks et al. 1998, 2001; Marks and Winstral 2001). Spatial variability in snowmelt can strongly influence water discharge (Seyfried and Wilcox 1995; Luce et al. 1998), plant communities and ecology (Barron et al. 1993; Flerchinger and Cooley 2000), water chemistry (Woolford et al. 1996), and hillslope erosion (Tarboton et al. 1991).

In Himalayan mountains, assessment of vulnerability to hydro-meteorological hazards requires good understanding of precipitation extremes (Karki et al. 2017; Panday et al. 2014; Roy 2008; 
Sanjay et al. 2017; Sigdel and Ma 2017). However, it is difficult to obtain spatial information from this region due to scarcity and uneven distribution of in situ weather observations leading to delineation of sharp precipitation gradients that classifies this region difficult (Anders et al. 2006). Spatial information of precipitation from the long term daily gridded datasetAPHRODITE (Asian Precipitation Highly Resolved Observational Data Integration Towards Evaluation of Water Resources; Yatagai et al. 2012) is also difficult to obtain for this region due to requirement of in situ measurements. The accuracy of this method is severely compromised in Hindu Kush and Karakoram Himalayas both due to data scarcity and inadequacies in interpolation methods (Bhardwaj et al. 2017; Hussain et al. 2017). The TRMM (Tropical Rainfall Measuring Mission; Huffman et al. 2007) satellite estimates of gridded precipitation dataset is unable to incorporate orographic effect on precipitation and hence it also needs adjustment using in situ measurements (Andermann et al. 2011; Yin et al. 2008). The gridded weather data can be obtained by using a regional climate model to dynamically downscale coarser resolution reanalysis or global climate model data to high spatial resolution. The downscaled data may further be post processed for correction of biases so that it could match with the observations. Though, many researchers have shown importance of bias correction over complex topographies (Bordoy and Burlando 2013; Lafon et al. 2013; Teutschbein and Seibert 2012), yet its application and usefulness has to be verified over Himalayas (Shrestha et al., 2017). Bannister et al (2019) attempted bias correction of WRF model output at $5 \mathrm{~km}$ grid spacing to reproduce spatiotemporal variability of precipitation for two basins of the Himalaya. They used a power transformation for bias correction as proposed by Leander and Buishand (2007).

Complex spatial variation of precipitation over mountains makes it challenging to construct gridded precipitation dataset for these regions. The precipitation distribution depends on height and scale of the obstacle and the strength, static stability and moisture profile of the impinging 
flow and complex topographic shapes, transient weather systems, convection, and the drift of hydrometeors make this distribution more complicated (Cosma et al. 2002; Fuhrer and Schär, 2005; Houze et al. 2001; Roe 2005; Sinclair et al. 1997; Steiner et al. 2003). Generation of weather data at sub-kilometer grid resolution using fully dynamic, regional atmospheric models have been found computationally prohibitive (Liston et al. 1999; Liston and Pielke 2001). Simple interpolation schemes may not account for naturally occurring meteorological gradients. Liston and Elder (2006) developed an intermediate-complexity, quasi-physically based, meteorological model (MicroMet) to produce sub-kilometer grid resolution atmospheric variables. They used Barnes objective analysis scheme (Barnes 1964) with some corrections to the interpolated fields using known temperature-elevation, wind-topography, humiditycloudiness, and radiation-cloud-topography relationships. These known relationships and development of non-linear relationships between observed and simulated weather variables at maximum possible grid locations can provide high resolution spatial map of weather variables with good accuracy.

In the present study, WRF model output variables such as maximum temperature, minimum temperature, wind speed, relative humidity, snowfall and snow depth are generated at a spatial resolution of $2 \mathrm{~km}$ and post-processed using observed data of five locations in ChowkibalTangdhar region of the North-West Himalaya. The post-processed variables have been spatially interpolated to a grid resolution of $90 \mathrm{~m}$ using inverse distance weighing scheme and quasi-physical relations as used by Liston and Elder (2006). Month wise lapse rates used in quasi-physical equations for maximum temperature, minimum temperature, snowfall and snow depth have been derived from the observed data of five locations in the C-T region.

\section{Study area and data}

WRF model simulations have been carried out with spatial resolution of $2 \mathrm{~km}$ for 11 winters from 2009 to 2019 over an area of 260 x $260 \mathrm{~km}^{2}$ approx. lying between $32.90-35.24 \mathrm{~N}$ and 

Laddakh region of the India. Out of this simulation domain, an area of approximately 14 x 10 $\mathrm{km}^{2}$ lying between $34.38-34.47 \mathrm{~N}$ and 73.88 - 74.03 E comprising Chowkibal-Tangdhar region of $\mathrm{J} \& \mathrm{~K}$, India has been selected for generation of ultra-high resolution meteorological fields (Fig 1). Northern and North-West parts of the C-T region fall in Pir-Panjal and Southern and South-East parts in the Shamshabari mountain range of the Himalaya. The elevation of this region varies from 1600 to $4000 \mathrm{~m}$ with an average altitude of $2000 \mathrm{~m}$. In the C-T region, there are four automatic and one manual meteorological data observation points (Station-1 to 5 are shown in Fig 1) with their altitudes lying between 2600 and 3400 m. Data collected from these stations has been used for post-processing of WRF output and spatial interpolation of the postprocessed data.

Atmospheric initial and boundary conditions for the WRF model have been obtained from the FNL reanalysis data and topographic and land cover data obtained from USGS and MODIS, respectively. The observed meteorological variables used in the study involve maximum and minimum temperatures, ambient temperature, atmospheric pressure, wind speed, relative humidity, snow depth, sunshine duration and snowfall. The meteorological variables to be postprocessed are extracted from WRF output at 03 (0830 IST) and 12 UTC (1730 IST) because of availability of observed data at these time steps. Manual data of Station-1 is available since 1992 whereas automatic weather data of Station-2 to 5 is available since commencement of automatic weather stations at these locations in Dec 2017. Hence, past weather data for Station2 to 5 for the desired period from 2009-2017 has been generated by developing a non-linear relationship between the manual data of Station-1 and AWS data of rest of the stations using artificial neural network. Thus, snow-met data of all five stations is made available at 03 and 12 UTC in the C-T region for the period 2009-19 for post-processing and validation of WRF simulations. Geographical data such as distances, altitudes, slopes, aspects and curvatures of 
the study domain has been derived using geo-processing Software-ArcGIS 10.8 .0 and $30 \mathrm{~m}$

Digital Elevation Model (DEM).

\section{Methodology}

151 Different steps for generation of ultra-high resolution $(90 \mathrm{~m})$ meteorological fields over C-T region of the N-W Himalaya data are briefly explained as follows:

\subsection{WRF configuration and hind cast run with $2 \mathrm{~km}$ resolution over Himalaya}

WRF Ver 3.8 (Skamarock et al. 2005) has been used. It uses fully compressible non-hydrostatic dynamical core with terrain following pressure coordinates (Skamarock et al. 2008). Radiative transfer has been simulated using the RRTMG scheme (Iacono, 2008) that accounts for multiple bands, overlapping clouds and slope-based topographic shading effects. Bottom boundary conditions for the atmosphere have been provided by the Noah-MP land surface model (Niu et al. 2011; Yang et al. 2011) that simulates land-atmosphere sensible heat, latent heat and momentum fluxes. The model has been configured to run on a series of three nested domains with the innermost domain having 131x131 grid points of $2 \mathrm{~km}$ resolution.

WRF was configured to simulate the weather over an approximately $260 \times 260 \mathrm{~km}^{2}$ domain covering most of the J\&K and part of the Laddakh region of the North-West Himalaya (Fig 1).

This domain has been discretized with a rectangular Cartesian grid in the horizontal with $131 \times 131$ points at $2 \mathrm{~km}$ resolution and nested within 2 coarser domains of sizes $780 \times 780 \mathrm{~km}^{2}$ and $2340 \mathrm{x} 2340 \mathrm{~km}^{2}$, respectively, with resolutions of $6 \mathrm{~km}$ and $18 \mathrm{~km}$, respectively. Each domain went up to $10 \mathrm{~km}$ altitude in the vertical direction, having 27 vertical levels between resolution simulations has been used. the surface and the model top. WRF Single-Moment 6-class parameterization scheme (Hong and Lim 2006) that includes, cloud, liquid water, ice, snow and graupel processes for high-

\subsection{Deduction of relationship between manual and automatic weather data}


In the C-T Region meteorological data has been collected through four AWSs and one manual meteorological observatory. Snow and meteorological data of AWS is available from Station2 to 5 since Dec 2017 and that from manual observatory at Station-1 since Nov 1992. Postprocessing of WRF model output at these observation points requires continuous data of these locations for the same period as that of WRF hindcast run (2009-19). To enable continuity of snow and meteorological data at AWS locations for the period 2009-17, it has been generated by developing non-linear relationship between manual and AWS data using artificial neural network. The ANN has been developed using data of two winters (2017-19) and validated for the winter 2019-20. Maximum and minimum temperature, wind speed, relative humidity, snowfall, and snow depth has been generated for all four AWS locations. The model input variables for generation and post-processing of different weather variables are summarised in Table 1. The working procedure of the ANN has been summarised in the following section.

\subsection{Post-processing of WRF output}

WRF model output has been post-processed at five different locations in the C-T region using observed data of these locations. ANNs have been developed for post processing of desired WRF output variables for all five locations. The ANN input variables include observed maximum, minimum and ambient temperature, wind speed, relative humidity, fresh snow, standing snow, atmospheric pressure and sun shine hour. Additionally, a previous day observed variable that has to post processed has also been taken as input in the ANN. There are 8 neurons in the input layer, 5 in the hidden layer and one in the output layer of each ANN. Both at the hidden and the output layer, sigmoid activation function has been used. A gradient descent technique has been used for optimization of the neural network for upgradation of weights and biases of the neurons. The working of the ANN has been briefly summarised as follows:

\subsubsection{Artificial Neural Network}


ANN is a set of connected input and output units, where each connection has a weight associated with it. Neurons are the fundamental processing unit of the neural network. It receives inputs, combines them, performs a generally nonlinear operation on the result depending on the activation function used and outputs the final result. It uses gradient descent approach to minimize the error function to achieve global minimum. It learns by updating the weights to classify the data. Single hidden layer ANNs consist of mainly three parts- feed forward (providing input and propagating the output from hidden layer neuron), back propagation of error and updating weights. Neural learning is an iterative process of learning by back propagating and adjusting weights. For each sample, weights are modified to minimize the error between network's classification and actual classification. It is advised that training dataset must contain data points minimum 10 times to the total network weights that are to be trained for proficient learning. Neural network processing is briefly described in the following steps:

\section{Step-I: initialization of weights and biases}

The weights and bias are initialized to random numbers between 0 and 1 .

\section{Step-II: Normalization of inputs}

All the inputs are normalized according to the choice of activation function (between 0 and 1 or -1 and 1$)$

\section{Step-III: Feed forward process}

Feed forward process is applied to each neuron in the hidden and output layers and error is computed at the output layer. Each neuron in the hidden and output layers takes its formalized input and applies activation function. The activation function can be logistic, sigmoid, hyperbolic or softmax etc. making neural network nonlinear in nature. At the hidden and output layer, summation of weighted values of the neurons and biases is carried out as follows:

$$
\sum w_{i j} o_{j}+\theta_{\mathrm{j}}
$$


221 Where, $\theta_{\mathrm{j}}$ is the bais of the hidden layer at neuron $\mathrm{j}$, and $w_{i j}$ are the input weights from $\mathrm{i}^{\text {th }}$ input

222

223

224 neuron to $\mathrm{j}^{\text {th }}$ hidden neuron.

The above weighted sum at the output of each neuron in the hidden and output layer is passed through an activation function to produce the output. The choice of activation function depends on the type of model to be developed. We have used a sigmoid function as defined below:

Computation of error at the output neuron depends upon the type of activation function used at the output neuron. Error at the output neuron for sigmoid function is given by the following expression:

$$
\mathrm{E}_{\mathrm{k}}=\mathrm{O}_{\mathrm{k}}\left(1-\mathrm{O}_{\mathrm{k}}\right) X\left(\mathrm{~T}_{\mathrm{k}}-\mathrm{O}_{\mathrm{k}}\right)
$$

Where $\mathrm{O}_{k}$ is output of unit $\mathrm{k}$ of the network and $\mathrm{T}_{\mathrm{k}}$ is observed/known output. $\mathrm{O}_{\mathrm{k}}\left(1-\mathrm{O}_{\mathrm{k}}\right)$ represents a derivative (rate of change) of the activation function which as part of error to be propagated backward to adjust weights.

\section{Step-IV: Back propagation of error}

The error at the output neuron is back propagated to the hidden neuron. For a neuron $\mathrm{j}$ in the hidden layer the back propagated error is computed as follows:

$$
E_{j}=O_{j}\left(1-O_{j}\right) X\left(\sum E_{k} w_{j k}\right)
$$

Where $\mathrm{w}_{\mathrm{jk}}$ is the weight of the connection from neuron $\mathrm{j}$ to neuron $\mathrm{k}$ in the next higher layer, and $E_{k}$ is the error of the output neuron $k$.

\section{Step-V: Upgradation of weights and biases}

The objective of training the neural network is to find a set of network weights such that the error at output is minimised. This is done by incrementally changing the weights along the direction of error gradient with respect to weights using learning rate (1). It is preferable to use low value of the learning rate for more efficient upgradation of the weights. Smaller learning rate and large number of iterations lead to achieve global minima. Both bias and weights are updated in similar manners as per the following equations: 


$$
\Delta w_{i j}=(l) E r r_{j} O_{i}
$$

$$
w_{i j}=w_{i j}+\Delta w_{i j}
$$

Where $\mathrm{w}_{\mathrm{ij}}$ are the weight of the connection between neuron $\mathrm{i}$ and $\mathrm{j}$.

$$
\begin{aligned}
& \Delta \theta_{j}=(l) E r r_{j} \\
& \theta_{j}=\theta_{j}+\Delta \theta_{j}
\end{aligned}
$$

251

252

253

254

Where $\theta_{\mathrm{j}}$ is the bias of neuron $\mathrm{j}$.

Insertion of momentum (m) is an optimization of the neural network. It is carried out to smooth the variation occurred as a result of changing gradient. Insertion of momentum, accelerates the network to attain global minima. This term (momentum multiplied by change in the weight) is added at the time of upgradation of weights as follows:

$$
w_{i j}=w_{i j}+\Delta w_{i j}+m\left(w_{i j}(n)-w_{i j}(n-1)\right)
$$

$\mathrm{W}_{\mathrm{ij}}(\mathrm{n})$ represents the latest updated weight and $\mathrm{W}_{\mathrm{ij}}(\mathrm{n}-1)$, the previously updated weight.

$$
\theta_{j}=\theta_{j}+\Delta \theta_{j}+m(\theta j(n)-\theta j(n-1))
$$

$\Theta_{j}(n)$ is the latest updated bias and $\Theta_{j}(n-1)$, the previous updated value of the bias.

\section{Step-VI: Termination}

The iterative process of upgradation of weights can be terminated at either some number of iterations or at some desired output error is achieved.

\subsection{Generation of ultra-high resolution $(90 \mathrm{~m})$ meteorological fields over C-T region}

The post processed WRF output variables such as Maximum, minimum and ambient temperature, wind speed, relative humidity, fresh snow and standing snow have been spatially interpolated to a grid resolution of $90 \mathrm{~m}$ using inverse distance weighing and quasi physical relations similar to that used by Liston and Elder (2006). We have derived month wise lapse rates for temperature, precipitation and snow depth for $\mathrm{C}-\mathrm{T}$ region of the Himalaya assuming a linear variation of these variables with elevation. Computation of lapse rates of these variables 
and generation of ultra-high resolution meteorological field of different weather variables have been briefly explained as follows:

\subsubsection{Temperature}

To derive the lapse rate for temperature, we have used the following linear relationship of variation of air temperature with altitude:

$$
T_{i}=T_{j}-\alpha\left(Z_{i}-Z_{j}\right)
$$

Where $T, Z$ represent temperature, elevation and $i, j$ represents $i^{\text {th }}, j^{\text {th }}$ grids respectively. the lapse rate in $\mathrm{m}^{-1}$. Lapse rate computed using this formulation for different months of our concern (Dec, Jan, Feb and Mar) has been summarized in Table 2. This lapse rate has been applied to the post processed temperature of WRF for computation of temperature at a desired grid of $90 \mathrm{~m}$ resolution using nine nearest grids based on the IDW scheme as follows:

$$
\mathrm{T}_{90 \mathrm{~m}}=\sum \mathrm{W}_{\mathrm{i}}\left(\mathrm{T}_{\mathrm{i}}-\alpha\left(\mathrm{Z}_{\mathrm{i}}-\mathrm{Z}_{90 \mathrm{~m}}\right)\right) / \sum \mathrm{W}_{\mathrm{i}}, \mathrm{i}=1 \text { to } 5
$$

Where $\mathrm{Ti}$ and $\mathrm{Zi}$ represent temperature and elevation of $\mathrm{i}^{\text {th }}$ grid respectively.

These relations have been used to deduce maximum, minimum and ambient temperatures.

\subsubsection{Snowfall}

To compute snowfall distribution over the C-T domain, first a precipitation adjustment factor has been computed (Table 2) for different months using snowfall data of five different elevations in the region using following non-linear expression as used by Liston and Elder (2006):

$$
\chi=\left(\mathrm{P}-\mathrm{P}_{0}\right) / 2 \mathrm{P}_{0}\left(\mathrm{Z}-\mathrm{Z}_{0}\right)
$$

Corresponding to a desired grid elevation $\left(Z_{90 m}\right)$, snowfall amount of neighboring five station grids of WRF has been brought to that elevation to compute snowfall at that grid $\left(\mathrm{P}_{90 \mathrm{~m}}\right)$ using IDW as follows:

$$
\mathrm{P}_{90 \mathrm{~m}}=\sum \mathrm{w}_{\mathrm{i}}\left(\mathrm{P}_{\mathrm{i}}\left(\left(1+\chi\left(\mathrm{Z}_{90 \mathrm{~m}}-\mathrm{Z}_{\mathrm{i}}\right)\right) /\left(1-\chi\left(\mathrm{Z}_{90 \mathrm{~m}}-\mathrm{Z}_{\mathrm{i}}\right)\right)\right) / \sum \mathrm{w}_{\mathrm{i}}, \mathrm{i}=1 \text { to } 5\right.
$$

Where, $\mathrm{Pi}$ and $\mathrm{Z}_{\mathrm{i}}$ represent snowfall and elevation of $\mathrm{i}^{\text {th }}$ grid. 


\subsubsection{Wind speed}

296 Generation of wind field at high spatial resolution over C-T region involves the use of

297 topographic variables such as slope $(\beta)$, azimuth or aspect $(\xi)$ and curvature $\left(\Omega_{c}\right)$. These topographic variables have been derived from Digital Elevation Model (DEM) of the region available at $30 \mathrm{~m}$ resolution. The curvature and slope in the direction of wind $\left(\Omega_{\mathrm{s}}\right)$ has been normalized over the C-T domain between -0.5 and 0.5 using min-max normalization. Slope in the direction of the wind has been computed by using the following relation (Liston and Elder 2006):

$$
\Omega_{\mathrm{s}}=\beta \cos (\theta-\xi)
$$

where $\theta$ is observed wind direction at nearest AWS station.

Using slope and curvature weights $\gamma_{\mathrm{s}}$ and $\gamma_{\mathrm{c}}$ respectively, wind weighing factor $\left(\mathrm{W}_{\mathrm{w}}\right)$ and terrain modified wind speed $\left(\mathrm{W}_{90 \mathrm{~m}}\right)$ has been computed as follows:

$$
\begin{gathered}
\mathrm{W}_{\mathrm{w}}=1+\gamma_{\mathrm{s}} \Omega_{\mathrm{s}}+\gamma_{\mathrm{c}} \Omega_{\mathrm{c}} \\
\mathrm{W}_{90 \mathrm{~m}}=\sum \mathrm{W}_{\mathrm{i}}\left(\mathrm{W}_{\mathrm{w}} \mathrm{x} \mathrm{W}_{\mathrm{i}}\right) / \sum \mathrm{W}_{\mathrm{i}}, \mathrm{i}=1 \text { to } 5
\end{gathered}
$$

Where, $\mathrm{W}_{\mathrm{i}}$ represents wind speed at $\mathrm{i}^{\text {th }}$ grid point in the WRF output and $\mathrm{w}_{\mathrm{i}}$, the inverse of distance between the desired $90 \mathrm{~m}$ grid and the neighboring station grid.

\subsubsection{Relative humidity}

Since relative humidity vary non-linearly with altitude, its adjustment with altitude has been carried out using relatively linearly varying dry bulb and wet bulb temperatures in a similar way as carried out by Liston and Elder (2006). First, due point temperature $\left(\mathrm{T}_{\mathrm{d}}\right)$ at $2 \mathrm{~km}$ resolution has been computed using ambient temperature (T) and relative humidity (RH) as follows:

$$
\mathrm{e}_{\mathrm{s}}=\mathrm{a} \operatorname{Exp}\left(\frac{\mathrm{bT}}{\mathrm{c}+\mathrm{T}}\right)
$$

$$
\mathrm{RH}=100 \frac{e}{e_{s}}
$$




$$
\mathrm{T}_{\mathrm{d}}=\frac{c \ln \left(\frac{e}{a}\right)}{b-\ln \left(\frac{e}{a}\right)}
$$

Where, $\mathrm{e}_{\mathrm{s}}(\mathrm{Pa})$ is saturation vapor pressure, $\mathrm{a}=611.21 \mathrm{~Pa}, \mathrm{~b}=22.452$ and $\mathrm{c}=272.55^{\circ} \mathrm{C}$ (for ice) as given in (Buck 1981) and e (pa), the actual vapor pressure.

The dew point temperature can be adjusted in a similar way as the ambient temperature using dew point temperature lapse rate, $\digamma_{\mathrm{d}}\left({ }^{0} \mathrm{Cm}^{-1}\right)($ Kunkel 1989) as follows:

$$
\Gamma_{\mathrm{d}}=\lambda \frac{c}{b}
$$

Where, $\lambda\left(\mathrm{m}^{-1}\right)$ is a vapor pressure coefficient varying monthly. As there has not been found much variation in the value of $\lambda$ during winter, a constant value of 0.41 used.

The dew point temperature computed at $2 \mathrm{~km}$ grid resolution has been downscaled to $90 \mathrm{~m}$ resolution using dew point lapse rate and the IDW in a similar way as that for ambient temperature. These gridded dew point and ambient temperature values can be used to compute both normal and saturation vapor pressures for computation of relative humidity.

\subsubsection{Snow depth}

Time series plots of snow depth of different stations of the C-T region revel a linear variation of snow depth with elevation. Therefore, a linear relationship has been established between snow depth of five different locations in the C-T region for computation of snow depth adjustment factor $(\mu)($ Table-2) for different months of winter as follows:

$$
\mathrm{SD}_{\mathrm{j}}=\mathrm{SD}_{\mathrm{i}}+\mu\left(\mathrm{Z}_{\mathrm{j}}-\mathrm{Z}_{\mathrm{i}}\right) ; \mathrm{i}, \mathrm{j}=1 \text { to } 5
$$

Where SD represents snow depth and $\mathrm{Z}$ represents elevation.

The snow depth adjustment factor and post processed snow depth of WRF has been used to generate snow depth map at a spatial resolution of 90m using IDW as follows:

$$
\mathrm{SD}_{90 \mathrm{~m}}=\sum \mathrm{w}_{\mathrm{i}}\left(\mathrm{SD}_{\mathrm{i}}+\mu\left(\mathrm{Z}_{90 \mathrm{~m}}-\mathrm{Z}_{\mathrm{i}}\right)\right) / \sum \mathrm{w}_{\mathrm{i}}, \mathrm{i}=1 \text { to } 5
$$

341 Where, $\mathrm{w}_{\mathrm{i}}$, represents inverse of distance between the desired $90 \mathrm{~m}$ grid and the $\mathrm{i}^{\text {th }}$ neighboring station grid. 


\section{Results and discussion}

344 Post-processing and validation of WRF output has been carried out using data of 04 automatic weather stations and one manual observatory in the $\mathrm{C}$-T region. It requires continuous snow and meteorological data of same duration as that of the WRF model simulation i.e. 11 winters (2009-19). As AWS was available only for a duration of two winters (2017-19), remaining data for AWS locations has been generated by developing non-linear relationship between observed manual and AWS data using artificial neural network. The generated data has been validated through computation of root mean square error (RMSE) using leave one out cross validation method. The RMSE and standard deviation of generated weather data for four AWS locations has been summarized in Table 3. The RMSE vary between $\mathrm{x}$ and $\mathrm{y}$ for maximum temperature, $\mathrm{x}$ and $\mathrm{y}$ for minimum temperature, $\mathrm{j}$ and $\mathrm{k}$ for wind speed, $\mathrm{p}$ and $\mathrm{q}$ for relative humidity, $\mathrm{r}$ and $\mathrm{s}$ for snowfall in $24 \mathrm{~h}$ and $\mathrm{s}$ and $\mathrm{t}$ for snow depth. The RMSEs of all the generated variables for all four stations has been found considerably smaller than their standard deviation indicating that the ANN has reproduced observed data with considerable accuracy. The ANNs for generation of weather variables have been trained with different sets of hyper parameters and the set with the lest error (RMSE) has been taken for testing and validation of the model. Though the ANN has been tested with a number of combinations of the hyper parameters, it can further be trained with larger data set and different choices of hyper parameters, activation functions and optimization algorithms to achieve better results.

Maximum temperature, minimum temperature, wind speed, relative humidity, snowfall and snow depth data of eight winters (2009-16) has been extracted for five locations in the C-T region from WRF output at 3 and 12 GMT for post-processing and two winters (2017-19) for validation. The post-processed variables of all five stations have been validated with observed data through computation of root mean square error and comparing with standard deviation of the variables. RMSE and standard deviation of WRF output variables with and without post- 
processing for all the stations has been summarized in Table-4. Though post-processing of WRF has been carried out using generated data of four locations and manually observed data of one station yet the RMSE of all the post-processed variables for all five stations has been found considerably low as compared to unprocessed WRF model and standard deviation of the variables. Thus, post-processing of WRF model using ANN is capable of reproducing weather variables of all five stations with considerably good accuracy.

Ultra-high resolution (90m) meteorological fields over the C-T domain, have been generated by spatial interpolation of post-processed WRF output. WRF output with and without interpolation and post-processing are shown in Fig 2. Spatially interpolated post-processed WRF output variables have been categorized in different ranges for categorical verification of these variables through computation of PC, HSS (Fig 3) and CSI. Computation of these validation scores are explained in Appendix 'A' of the manuscript. The CSI has been computed for different ranges of the variables for all five stations and summarized results of Station-3 in Table-5. Bias and NSE scores have also been computed for validation of WRF with and without post-processing and summarized in Table 6.

The scatter and line plots (Fig 4) of maximum and minimum temperature show that spatially interpolated post-processed data captures the seasonal pattern quite successfully throughout winter season. The NSE score of maximum and minimum temperature for all stations lying between 0.81 and 0.89 represents that the model is capable of reproducing observed maximum and minimum temperature satisfactorily. The NSE scores of most of the stations have been found better than those obtained by Sen Gupta and Tarboton (2016) for USU Doc Daniel site. Root mean square error of maximum and minimum temperature for all five stations has been found between 1.2 and $1.9{ }^{\circ} \mathrm{C}$. The RMSE for all stations has been found considerably smaller than the standard deviation of maximum and minimum temperature for each of the stations. 
reproduced with better accuracy as compared to the extreme ranges. Bias of maximum and minimum temperature for all stations has been observed positive except for station- 4 . The overall accuracy of prediction of both maximum and minimum temperature for all the stations vary between $70-80 \%$ except that of minimum temperature for station-3. A considerably good HSS (0.5-0.65) for all the station of C-T region revel that the model is capable of reproducing the observations with considerably good skill as compared to random forecast.

The NSE scores of wind speed for station-4 and 5 fall under "very good" category representing model's capability to reproduce these variables at a "very good" level. However, for other stations, smaller NSE scores represent "poor" performance of the model. A negative NSE score $(-0.74)$ of wind speed for station-1 can be attributed to calm wind conditions of this station even at the time of snow storms. This station is situated at foothill on leeward side with a little variation in the wind speed (SD $0.7 \mathrm{~km} / \mathrm{h}$ ). Though the RMSE of wind speed has been improved considerably (Table 4) after post-processing yet it has been found quite close to the SD. The CSI score for station-3 represents that the model has been able to predict wind speed in the range $1-2 \mathrm{~km} / \mathrm{h}$ with considerably good accuracy. However, it has shown considerably smaller CSI for other ranges of wind speed. The overall accuracy and the HSS of the model has been found considerably smaller than that for other variables. This discrepancy in wind speed likely reflect the challenge in representing local wind variability at DEM grid scale from regional information (Sen Gupta and Tarboton, 2016).

The NSE scores of relative humidity represent that the RH has been reproduced by the model at "very good" level for all five stations except for station-1. The model has performed for station-1 at "satisfactory" level. The overall accuracy and HSS of the model for all stations has been found considerably good with larger CSI for higher ranges of the RH (Table 5). The RMSE of RH for different stations lies in the range between 7.3 and $11.7 \%$. Though snowfall in $24 \mathrm{~h}$ has been reproduced by the model at "poor" level for most of the stations yet the overall 
accuracy of the model for all five stations has been found greater than $80 \%$. Moreover, both for snowfall and wind speed the NSE scores of all the stations have been found better than those obtained by Sen Gupta and Tarboton (2016). The RMSE of snowfall has also been found considerably smaller than that reported by Bannister et al. (2019) in their study on bias correction of high resolution regional climate model precipitation output for Himalayan catchments. The higher accuracy of the model for reproducing snowfall can be attributed to majority of non-precipitation events in the validation data. A considerably high value of PC and HSS prove that the model is able to reproduce snowfall makes the model better than the random forecast.

Snow depth, an important input for hydrological, glaciological and avalanche hazard prediction models has been reproduced with considerable accuracy (PC) and skill (HSS) for all the ranges of snow depth (Fig 3). The CSI of the model for higher and lower ranges of snow depth has been found considerably high as compared to middle ranges. This implies that the model is able to reproduce snow depth with better accuracy for extreme ranges as compared to the middle ranges. The NSE score of snow depth for all five stations revel that the model has performed for all the stations at "very good" level. The RMSE of post-processing and spatial interpolation of snow depth for all five stations has been found considerably smaller than the SD of snow depth for these stations. There has been found a considerable improvement in the RMSE of snow depth as compared to raw WRF model output.

437 Snowfall is an important component for building seasonal snow cover and has been found as one of the primary inputs for diverse applications such as hydrological, glaciological, energy balance and avalanche hazard prediction models. Snowfall in $24 \mathrm{~h}$ has been reproduced and compared with the observed snowfall at all five stations during major snowfall events during 2017-19 (Fig 5). Analysis of these storms reveal that the model has underperformed for station4421 and 2 with bias of -1.2 and -0.9 respectively. Rest of the stations have shown a positive bias. 
For Station-3 with considerably small positive bias (0.08) the model has performed at "satisfactory" level. The model has performed considerably good for all snow storms for which observed cumulative storm snow was less than $100 \mathrm{~cm}$. The model has under predicted extreme snowfall events most likely due to limited number of such events in the training set of the ANN.

\section{Conclusion}

Meteorological fields such as maximum and minimum temperature, wind speed, relative humidity, snowfall in $24 \mathrm{~h}$ and snow depth have been generated on a fine resolution grid (90 m) over Chowkibal-Tangdhar region of North-West Himalaya. These fields have been generated for development of snow cover and avalanche forecasting models for avalanche hazard assessment at high spatial resolution. In a two-step process, the first step is to postprocess WRF output using observed data of five stations in the C-T region. In the second step, spatial interpolation using inverse distance weighing and topographic adjustments of elevation, slope, aspect and curvature for the selected variables has been carried out. The selected variable have been reproduced with considerable accuracy for all five stations of the C-T region. The RMSE of different stations in the C-T region lies in the range of $1.2-1.9{ }^{0} \mathrm{C}$ for maximum and minimum temperature, $7.3-11.7 \%$ for relative humidity, $0.7-1.4 \mathrm{~km} / \mathrm{h}$ for wind speed, $3.2-$ $4.4 \mathrm{~cm}$ for snowfall in $24 \mathrm{~h}$ and $9.9-21 \mathrm{~cm}$ for snow depth. The NSE scores of the models for maximum and minimum temperature, relative humidity and snow depth have been found at "very good" (> 0.75) level with considerably good HSS $(>0.40)$. However, wind speed and snowfall in $24 \mathrm{~h}$ have shown "poor" NSE scores $(<0.5)$ with smaller HSS. This study can be extended for all three mountain ranges (Pir-Panjal, Great Himalayan and Karakoram ranges) management of hydro-meteorological hazards and study of energy balance for glaciological and climatological applications over Himalaya. 


\section{Acknowledgement}

469 This study was carried out under DRDO funded project- Him Sandesh. The authors are thankful to Director DGRE for sanctioning this project and providing technical and administrative support to execute the project. The authors are also thankful to Dr. SB Roy, Associate Professor, Department of Atmospheric Sciences, IIT Delhi for generating WRF data for DGRE. Project team members of Him Sandesh are duly acknowledged for field installation, maintenance and data collection of automatic weather stations.

\section{Appendix ' $\mathrm{A}$ '} calculated as follows:

$$
\begin{gathered}
\text { NSE }=1-\frac{\sum_{\mathrm{t}=1}^{\mathrm{n}}\left(\mathrm{O}_{\mathrm{t}}-\mathrm{S}_{\mathrm{t}}\right)^{2}}{\sum_{\mathrm{t}=1}^{\mathrm{n}}\left(\mathrm{O}_{\mathrm{t}}-\mathrm{O}_{\text {mean }}\right)^{2}} \\
\text { RMSE }=\sqrt{\frac{\sum_{\mathrm{t}=1}^{\mathrm{n}}\left(\mathrm{O}_{\mathrm{t}}-\mathrm{S}_{\mathrm{t}}\right)^{2}}{n}} \\
\text { Bias }=\frac{\sum_{t=1}^{n}\left(\mathrm{O}_{\mathrm{t}}-\mathrm{S}_{\mathrm{t}}\right)}{n}
\end{gathered}
$$

Where, $\mathrm{O}_{\mathrm{t}}$ and $\mathrm{S}_{\mathrm{t}}$ represent observed and simulated values at any time step $\mathrm{t}, \mathrm{O}_{\text {mean }}$ represents mean of the observed value and $\mathrm{n}$ represents total number of observations. NSE, a dimensionless metric, quantify error relative to variability, whereas RMSE and BIAS have the units of the quantity being evaluated and represent scale of the error. NSE ranges between 0 for simulations no better than picking the mean and 1 for observations equal to simulations. It can go negative even for worst performance. In common practice it has been interpret in the ranges $<0.5$ as "poor", $0.5-0.65$ "satisfactory", $0.65-0.75$ "good", and > 0.75 as "very good" (Kalra and Ahmad 2012; Moriasi et al. 2007).

II. In Table A, total number of observed events in category-1 are given by: $\mathrm{A}_{1}=\mathrm{C}_{11}+\mathrm{C}_{12}+\ldots+\mathrm{C}_{1 \mathrm{n}}$ 
Table A: $\mathrm{n}$ x $\mathrm{n}$ contingency table of observed and forecasted events

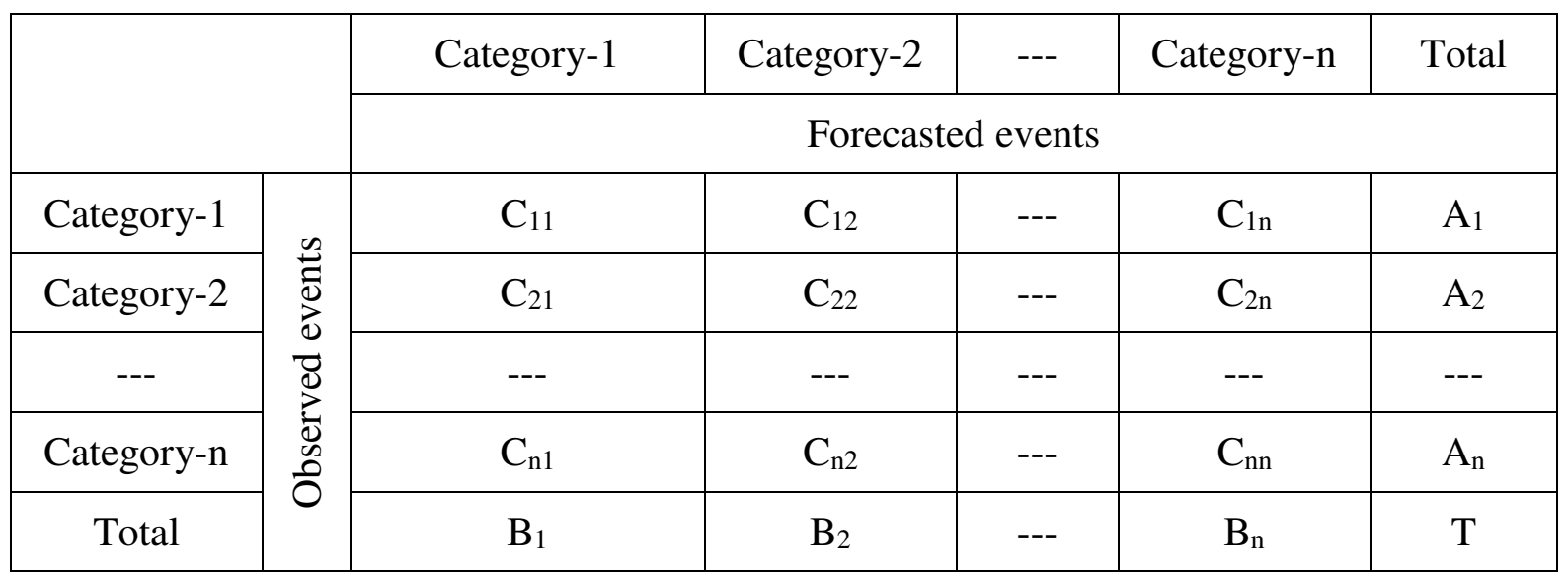

505 $\mathrm{B}_{1}=\mathrm{C}_{11}+\mathrm{C}_{21}+\ldots+\mathrm{C}_{\mathrm{n} 1}$

In a similar way, total number of observed and forecasted events in all the categories can be calculated.

Total number of events are given by:

$\mathrm{T}=\mathrm{A}_{1}+\mathrm{A}_{2}+\ldots+\mathrm{A}_{\mathrm{n}}=\mathrm{B}_{1}+\mathrm{B}_{2}+\ldots+\mathrm{B}_{\mathrm{n}}$

The Percentage correct is calculated as follows:

$$
\mathrm{PC}=\left(\left(\mathrm{C}_{11}+\mathrm{C}_{22}+\ldots+\mathrm{C}_{\mathrm{nn}}\right) / \mathrm{T}\right)
$$

The Critical success index in category ' $i$ ' is given by:

$$
\operatorname{CSI}(\mathrm{i})=\mathrm{C}_{\mathrm{ii}} /\left(\mathrm{A}_{\mathrm{i}}+\mathrm{B}_{\mathrm{i}}-\mathrm{C}_{\mathrm{ii}}\right)
$$

The Heidke skill score (HSS) is given by:

$$
\mathrm{HSS}=\left(\left(\sum \mathrm{C}_{\mathrm{ii}}\right)-\left(\sum \mathrm{A}_{\mathrm{i}} \mathrm{B}_{\mathrm{i}}\right) / \mathrm{T}\right) /\left(\mathrm{T}-\left(\sum \mathrm{A}_{\mathrm{i}} \mathrm{B}_{\mathrm{i}}\right) / \mathrm{T}\right)
$$




\section{Reference}

1. Andermann C, Bonnet S, and Gloaguen R (2011) Evaluation of precipitation data sets along the Himalayan front. Geochemistry, Geophysics, Geosystems, 12, Q07023.

2. Anders AM, Roe GH, Hallet B, Montgomery DR, Finnegan NJ, and Putkonen J (2006) Spatial patterns of precipitation and topography in the Himalaya. Geological Society of America Special Papers, 398, 39-53.

3. Balk B, and Elder K (2000) Combining binary decision tree and geostatistical methods to estimate snow distribution in a mountain watershed. Water Resources Research, 36(1), 1326.

4. Bannister D, Orr A, Jain SK, Holman IP, Momblanch A, Phillips T, et al. (2019) Bias correction of high-resolution regional climate model precipitation output gives the best estimates of precipitation in Himalayan catchments. Journal of Geophysical Research: Atmospheres, 124, 14, 220-239.

5. Barnes SL (1964) A technique for maximizing details in numerical weather map analysis. Journal of Applied Meteorology and Climatology, 3(4), 396-409.

6. Barron JS, Band LE, Running SW, and Cline D (1993) The effects of snow distribution on the hydrologic simulation of a high elevation Rocky Mountain watershed using Regional Hydro Ecological Simulation System, RHESSys. Eos Trans. AGU, 74 (43), 237.

7. Bhardwaj A, Ziegler AD, Wasson RJ, and Chow WTL (2017) Accuracy of rainfall estimates at high altitude in the Garhwal Himalaya (India): A comparison of secondary precipitation products and station rainfall measurements. Atmospheric Research, 188, 3038.

8. Bloschl GO and Kirnbauer R (1992) An analysis of snow cover patterns in a small alpine catchment. Hydrological Processes, 6 (1), 99-109. 
9. Bordoy R and Burlando P (2013) Bias correction of regional climate model simulations in a region of complex orography. Journal of Applied Meteorology and Climatology, 52, 82101.

10. Buck AL (1981) New equations for computing vapour pressure and enhancement factor. Journal of Applied Meteorology and Climatology, 20(12), 1527-1532.

11. Cosma S, Richard E and Miniscloux F (2002) The role of small-scale orographic features in the spatial distribution of precipitation. Quarterly Journal of the Royal Meteorological Society: A journal of the atmospheric sciences, applied meteorology and physical oceanography, 128 (579), 75-92.

12. Bannister D, Orr A, Jain SK, Holman IP, Momblanch A, Phillips T, et al. (2019) Bias correction of high-resolution regional climate model precipitation output gives the best estimates of precipitation in Himalayan catchments. Journal of Geophysical Research: Atmospheres,124, 14,220-14,239. https://doi.org/10.1029/ 2019JD030804

13. Doesken NJ and Judson A (1996) The Snow Booklet: A Guide to the Science, Climatology, and Measurement of Snow in the United States. 5 pp., Dep. of Atmos. Sci., Colo. State Univ., Fort Collins, Colo.

14. Elder K, Dozier J and Michaelsen J (1991) Snow accumulation and distribution in an alpine watershed. Water Resources Research, 27(7), 1541-1552.

15. Flerchinger GN and Cooley KR (2000) A ten-year water balance of a mountainous semiarid watershed. Journal of Hydrology, 237(1-2), 86-99.

16. Fuhrer O and Schär C (2005). Embedded cellular convection in moist flow past topography. Journal of the Atmospheric Sciences, 62(8), 2810-2828.

17. Hock R (2003) Temperature index melt modelling in mountain areas. Journal of hydrology, 282(1-4), 104-115. 
18. Holzkämper A, Calanca P and Fuhrer J (2012) Statistical crop models: predicting the effects of temperature and precipitation changes. Climate Research, 51(1), 11-21.

19. Hong SY and Lim JOJ (2006) The WRF single-moment 6-class microphysics scheme (WSM6). Asia-Pacific Journal of Atmospheric Sciences, 42(2), 129-151.

20. Houze Jr RA, James CN and Medina S (2001) Radar observations of precipitation and airflow on the Mediterranean side of the Alps: Autumn 1998 and 1999. Quarterly Journal of the Royal Meteorological Society, 127(578), 2537-2558.

21. Huffman GJ, Adler RF, Bolvin DT, Gu G, Nelkin EJ, Bowman KP, et al. (2007) The TRMM multi satellite precipitation analysis (TMPA): Quasi-global, multiyear, combinedsensor precipitation estimates at fine scales. Journal of Hydrometeorology, 8, 38-55.

22. Hussain S, Song X, Ren G, Hussain I, Han D, and Zaman MH (2017) Evaluation of gridded precipitation data in Hindu Kush- Karakoram-Himalaya mountainous area. Hydrological Sciences Journal, 62, 2393-2405.

23. Kalra A and Ahmad S (2012) Estimating annual precipitation for the Colorado River Basin using oceanic-atmospheric oscillations. Water Resour. Res., 48.

24. Karki R, Hasson US, Schickhoff U, Scholten T and Böhner J (2017) Rising precipitation extremes across Nepal. Climate, 5 .

25. Krähenmann S and Ahrens B (2010) On daily interpolation of precipitation backed with secondary information. Advances in Science and Research, 4(1), 29-35.

26. Kunkel KE (1989) Simple procedures for extrapolation of humidity variables in the mountainous western United States. Journal of Climate, 2 (7), 656-669.

27. Lafon T, Dadson S, Buys G and Prudhomme C (2013) Bias correction of daily precipitation simulated by a regional climate model: A comparison of methods. International Journal of Climatology, 33, 1367-1381. 
28. Leander R and Buishand TA (2007) Resampling of regional climate model output for the simulation of extreme river flows. Journal of Hydrology, 332, 487-496.

29. Liston GE and Elder K (2006) A meteorological distribution system for high-resolution terrestrial modeling (MicroMet). Journal of Hydrometeorology, 7(2), 217-234.

30. Liston GE and Pielke RA (2001) A climate version of the regional atmospheric modeling system. Theoretical and Applied Climatology, 68(3), 155-173.

31. Liston GE, Pielke RA and Greene EM (1999) Improving first-order snow-related deficiencies in a regional climate model. Journal of Geophysical Research: Atmospheres, 104(D16), 19559-19567.

32. Luce CH, Tarboton DG and Cooley KR (1998) The influence of the spatial distribution of snow on basin-averaged snowmelt. Hydrological Processes, 12(10-11), 1671-1683.

33. Machguth H, Paul F, Kotlarski S and Hoelzle M (2009) Calculating distributed glacier mass balance for the Swiss Alps from regional climate model output: A methodical description and interpretation of the results. Journal of Geophysical Research: Atmospheres, 114 (D19).

34. Marks D, Link T, Winstral A and Garen D (2001) Simulating snowmelt processes during rain-on-snow over a semi- arid mountain basin. Annals of Glaciology 32, 195-202.

35. Marks D and Winstral A (2001) The effect of variable patterns of snow deposition and drifting on snowmelt, runoff, and stream discharge in a semi-arid mountain basin. Proceedings of the Western Snow Conference, 69th (pp. 16-19).

36. Marks D, Kimball J, Tingey D and Link T (1998) The sensitivity of snowmelt processes to climate conditions and forest cover during rain-on-snow: A case study of the 1996 Pacific Northwest flood. Hydrological Processes, 12(10-11), 1569-1587. 
37. Moriasi D, Arnold J, Van Liew M. Bingner R, Harmel R and Veith T (2007) Model evaluation guidelines for systematic quantification of accuracy in watershed simulations. Trans. ASABE, 50 (2007) 885-900.

38. Niu, Guo-Yue, Zong-Liang Yang, Kenneth E Mitchell, Fei Chen, Michael B Ek, Michael Barlage, Anil Kumar, Kevin Manning, Dev Niyogi, Enrique Rosero, Mukul Tewari, Youlong Xia (2011) The community Noah land surface model with multi parameterization options (Noah-MP): 1. Model description and evaluation with local-scale measurements. J. Geophys. Res., 116, D12109.

39. Panday PK, Thibeault J and Frey KE (2014) Changing temperature and precipitation extremes in the Hindu Kush-Himalayan region: An analysis of CMIP3 and CMIP5 simulations and projections. International Journal of Climatology, 35, 3058-3077. https://doi.org/10.1002/joc.4192.

40. Prasad PVV, Craufurd PQ, Kakani VG, Wheeler TR and Boote KJ (2001) Influence of high temperature during pre- and post-anthesis stages of floral development on fruit-set and pollen germination in peanut Australian Journal of Plant Physiology 28: 233-240.

41. Roe GH (2005) Orographic precipitation. Annual Review of earth and planetary sciences, 33(1), 645-671.

42. Roy SS (2008) A spatial analysis of extreme hourly precipitation patterns in India. International Journal of Climatology, 29, 345-355.https://doi.org/10.1002/joc.1763.

43. Sanjay J, Krishnan R, Shrestha AB, Rajbhandari R and Ren GY (2017) Downscaled climate change projections for the Hindu Kush Himalaya region using CORDEX South Asia regional climate models. Advances in Climate Change Research, 8,185-198. https://doi.org/10.1016/j.accre.2017.08.003. 
44. Seyfried MS and Wilcox BP (1995) Scale and the nature of spatial variability: Field examples having implications for hydrologic modeling. Water Resources Research, 31(1), 173-184.

45. Shrestha M, Acharya SC and Shrestha PK (2017) Bias correction of climate models for hydrological modelling_-Are simple methods still useful? Meteorological Applications, 24, 531-539.

46. Sigdel M and Ma Y (2017) Variability and trends in daily precipitation extremes on the northern and southern slopes of the central Himalaya. Theoretical and Applied Climatology,130(1-2), 571-581. https://doi.org/10.1007/s00704-016-1916-5

47. Sinclair MR, Wratt DS, Henderson RD and Gray WR (1997) Factors affecting the distribution and spill over of precipitation in the Southern Alps of New Zealand: A case study. Journal of Applied Meteorology, 36(5), 428-442.

48. Skamarock WC, Klemp JB, Dudhia J, Gill DO, Barker DM, Wang W and Powers JG (2005) A description of the advanced research WRF version 2. NCAR Tech. Note.

49. Steiner M, Bousquet O, Houze Jr RA, Smull BF and Mancini M (2003) Airflow within major Alpine river valleys under heavy rainfall. Quarterly Journal of the Royal Meteorological Society: A journal of the atmospheric sciences, applied meteorology and physical oceanography, 129 (588), 411-431.

50. Tarboton DG, Al-Adhami MJ and Bowles DS (1991) A preliminary comparison of snowmelt models for erosion prediction. Western Snow Conference, Juneau, Alaska.

51. Teutschbein C and Seibert J (2012) Bias correction of regional climate model simulations for hydrological climate-change impact studies: Review and evaluation of different methods. Journal of Hydrology, 456-457, 12-29. 
 \\ 674}

675

52. Wolford RA, Bales RC and Sorooshian S (1996) Development of a hydro chemical model for seasonally snow-covered alpine watersheds: Application to Emerald Lake watershed, Sierra Nevada, California. Water Resources Research, 32(4), 1061-1074.

53. Yang ZL, Niu GY, Mitchell KE, Chen F, Ek MB, Barlage M, Longuevergne L, Manning K, Niyogi D, Tewari M and Xia Y (2011) The community Noah land surface model with multi-parameterization options (Noah-MP): 2. Evaluation over global river basins. J. Geophys. Res., 116, D12110.

54. Yatagai A, Kamiguchi K, Arakawa O, Hamada A, Yasutomi N and Kitoh A (2012) APHRODITE: Constructing a long-term daily gridded precipitation dataset for Asia based on a dense network of rain gauges. Bulletin of the American Meteorological Society, 93, $1401-1415$.

55. Yin ZY, Zhang X, Liu X, Colella M and Chen X (2008) An assessment of the biases of satellite rainfall estimates over the Tibetan Plateau and correction methods based on topographic analysis. Journal of Hydrometeorology, 9, 301-326.

(1)

(1)

(1)

8

(1)

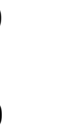

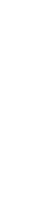

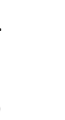

\section{3}




\section{Funding}

678 "The authors declare that no funds, grants, or other support were received during the 679 preparation of this manuscript."

\section{Competing Interests}

681 "The authors have no relevant financial or non-financial interests to disclose."

682 Author Contributions

"All authors contributed to the study conception and design. Material preparation, data

684 collection and analysis were performed by Dr Jagdish Chandra Joshi and Mrs Prabhjot Kaur.

685 The first draft of the manuscript was written by Dr Jagdish Chandra Joshi and all authors

686 commented on previous versions of the manuscript. All authors read and approved the final

687 manuscript."

\section{Data Availability}

689 "The datasets generated during and/or analysed during the current study are not publicly 690 available due to author's institution (DGRE) being a defence establishment." 

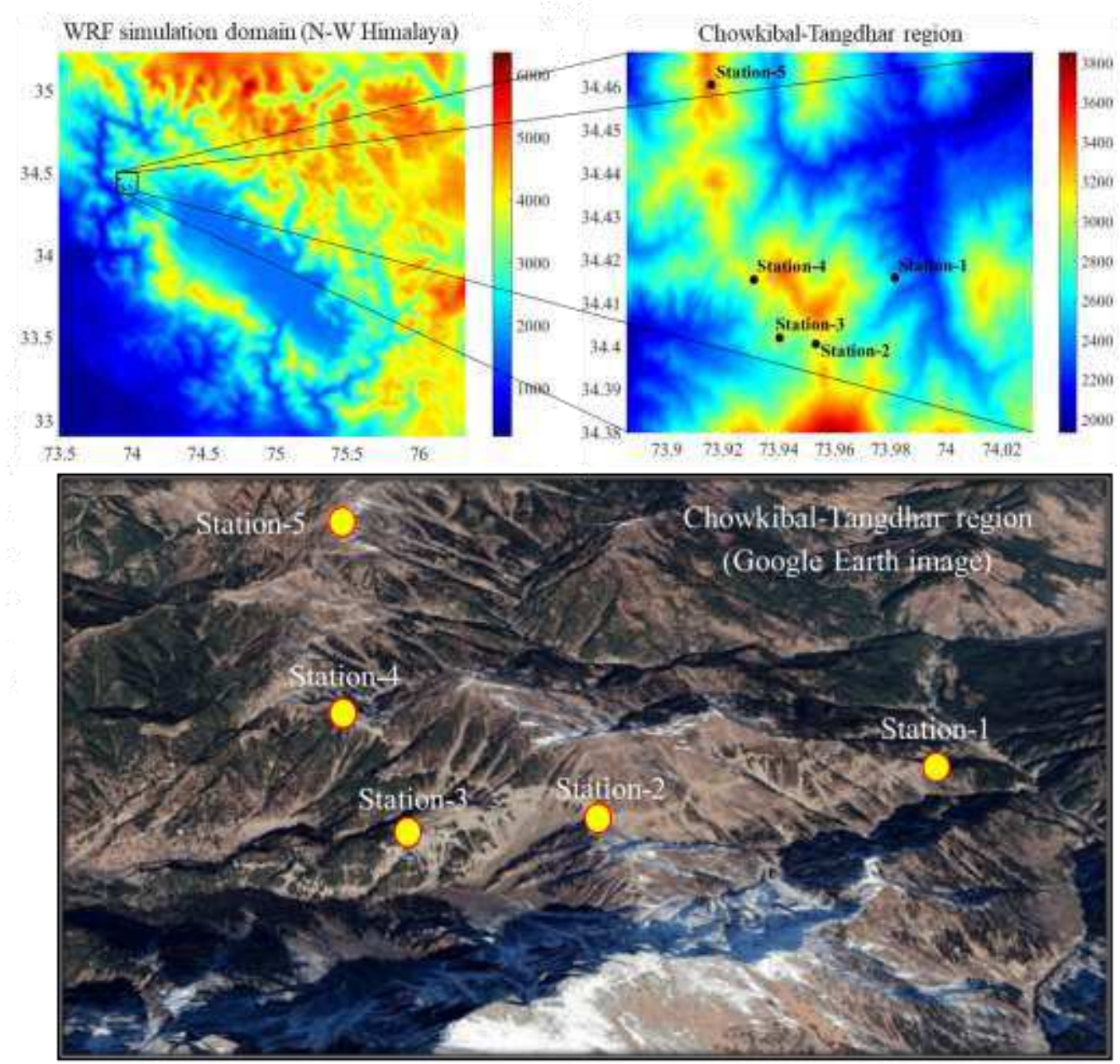

704 Fig 1: Altitude map of innermost domain (2km resolution) of WRF model and Chowkibal- 

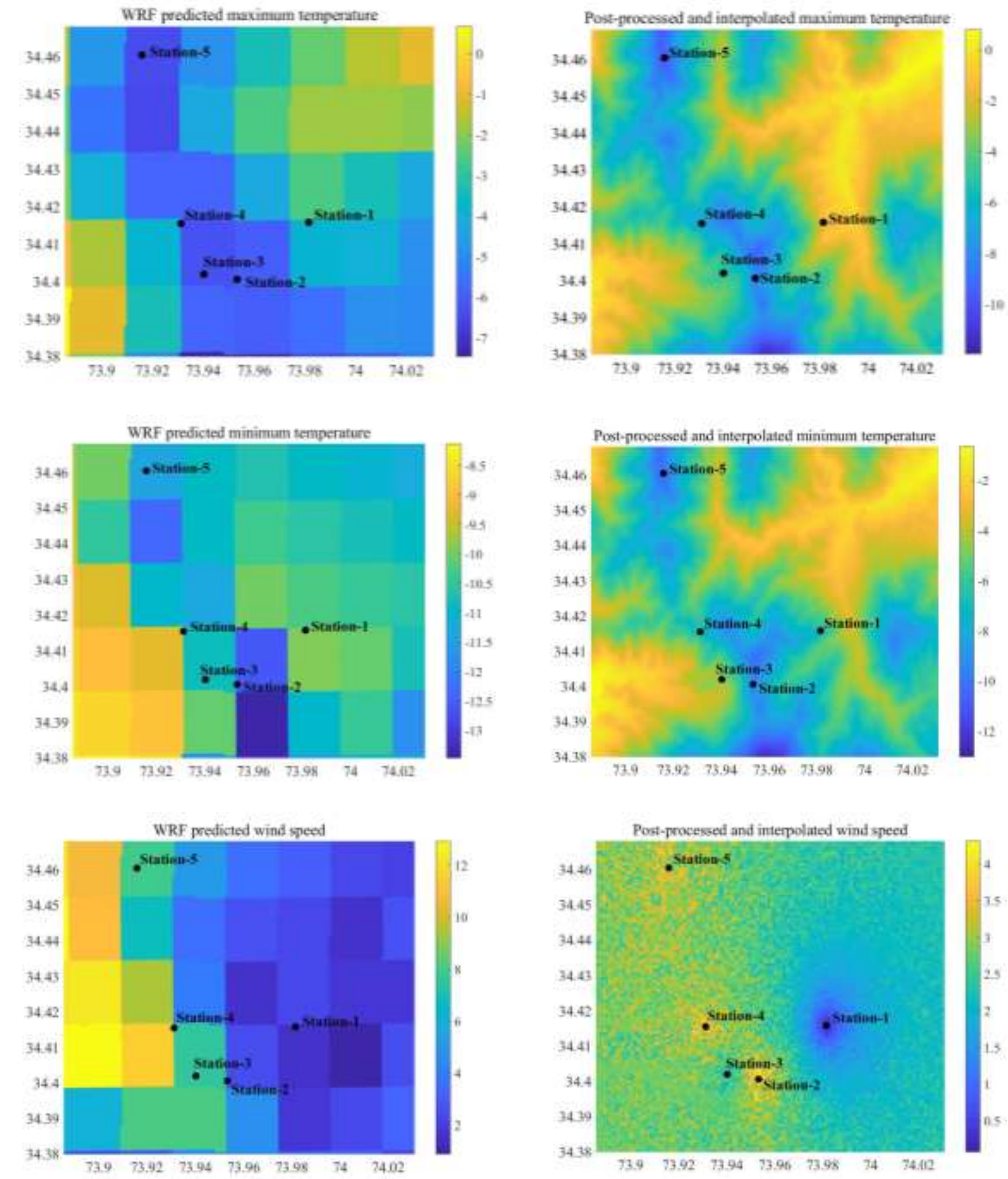

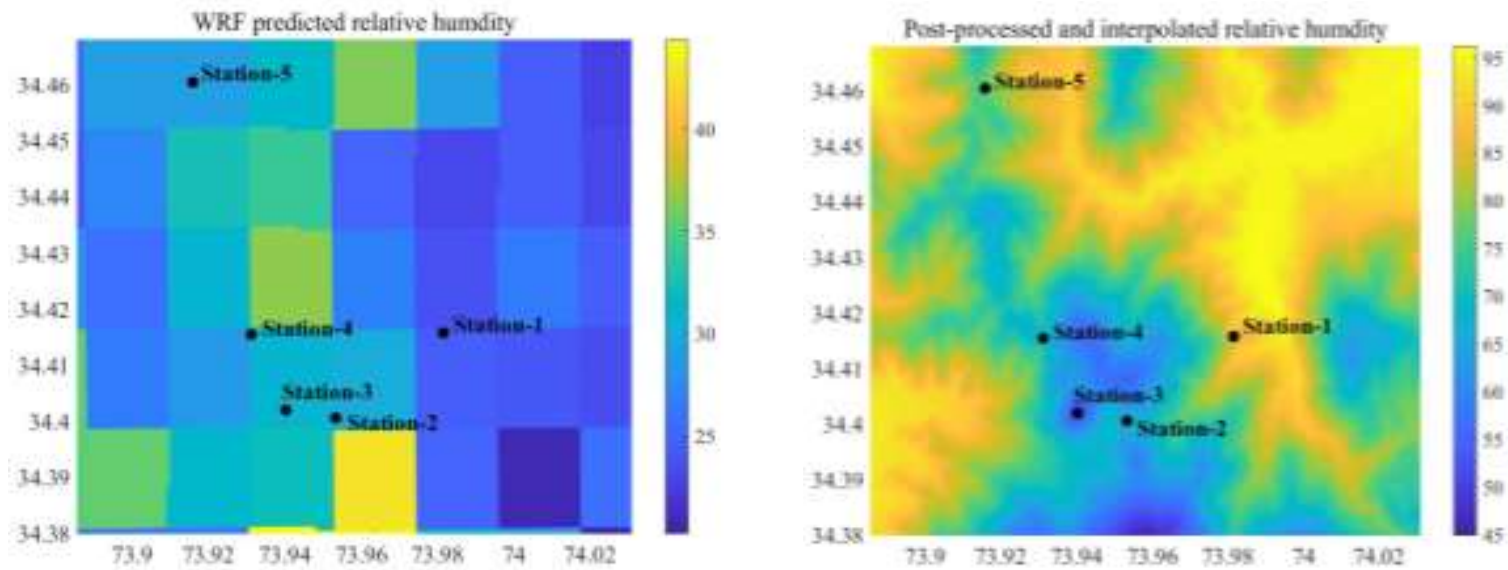

WRF predicted fresh snow
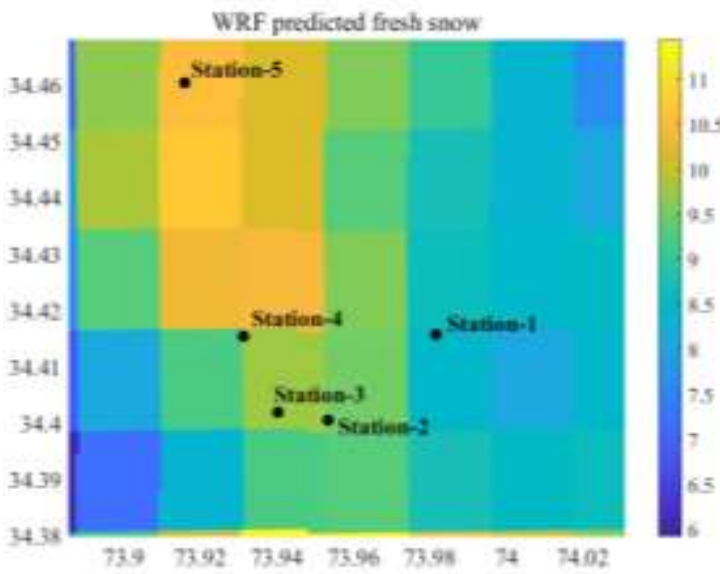

714
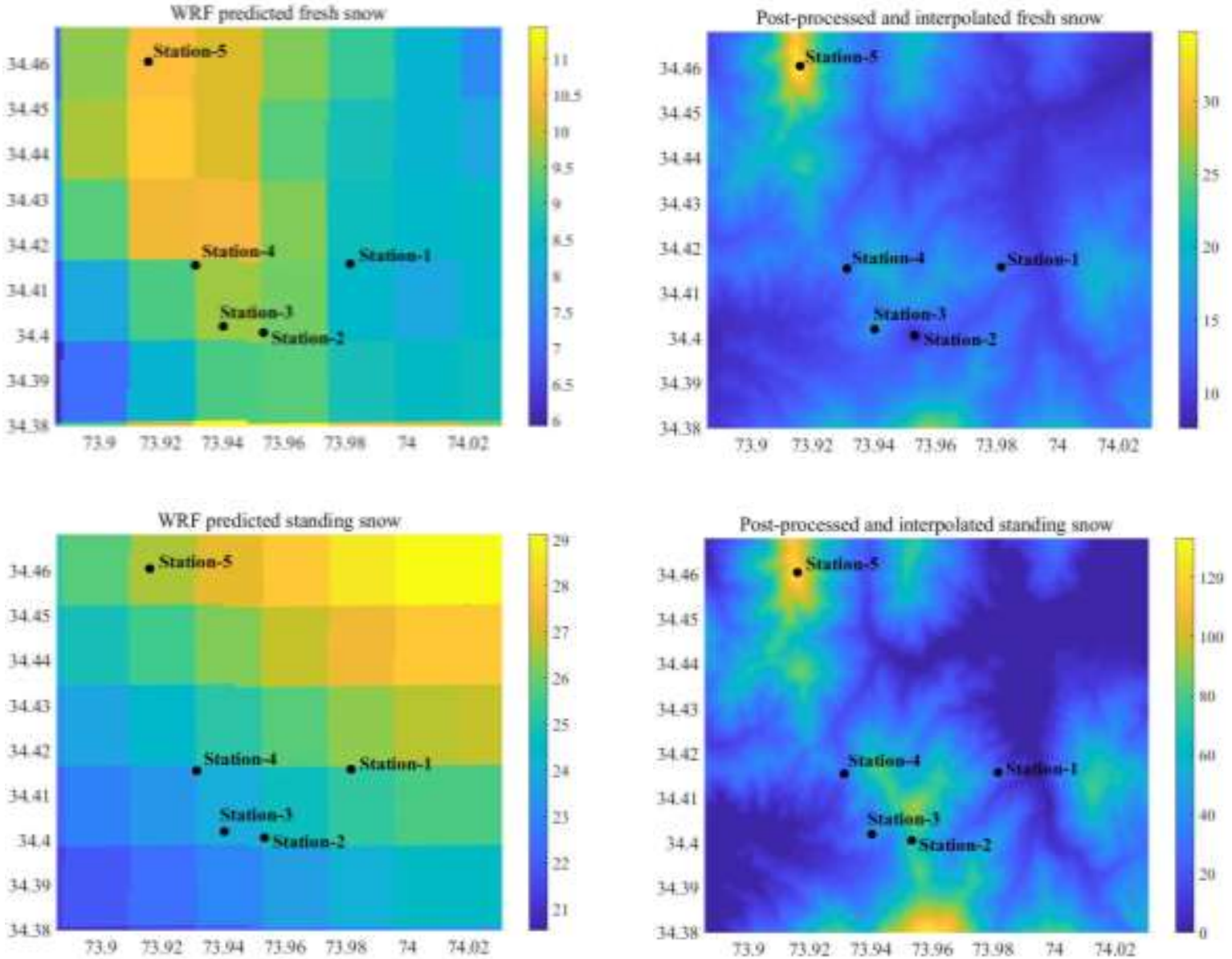

716 Fig 2: WRF output generated at $2 \mathrm{~km}$ resolution (left) and spatially interpolated post-processed

WRF output with $90 \mathrm{~m}$ resolution (right) producing maximum temperature, minimum temperature, relative humidity, average wind speed, snowfall in $24 \mathrm{~h}$ and snow depth for Chowkibal-Tangdhar region of North-West Himalaya 
723

724

725

726 


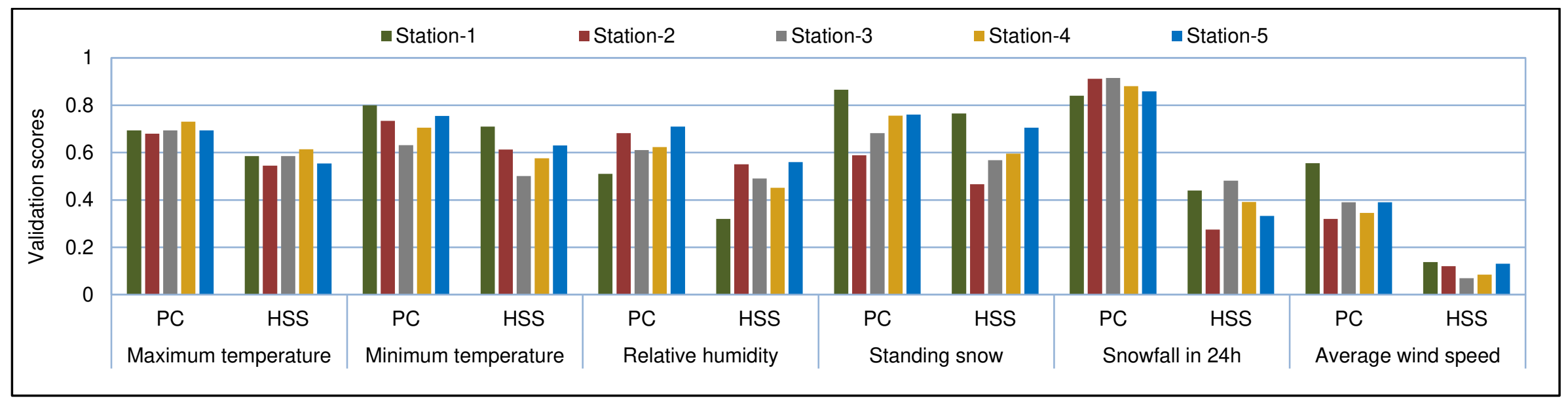

Fig 3: Percent Correct (PC) and Heidke Skill Score (HSS) of spatially interpolated post-processed WRF output variables for five stations in Chowkibal-Tangdhar region of

North-West Himalaya

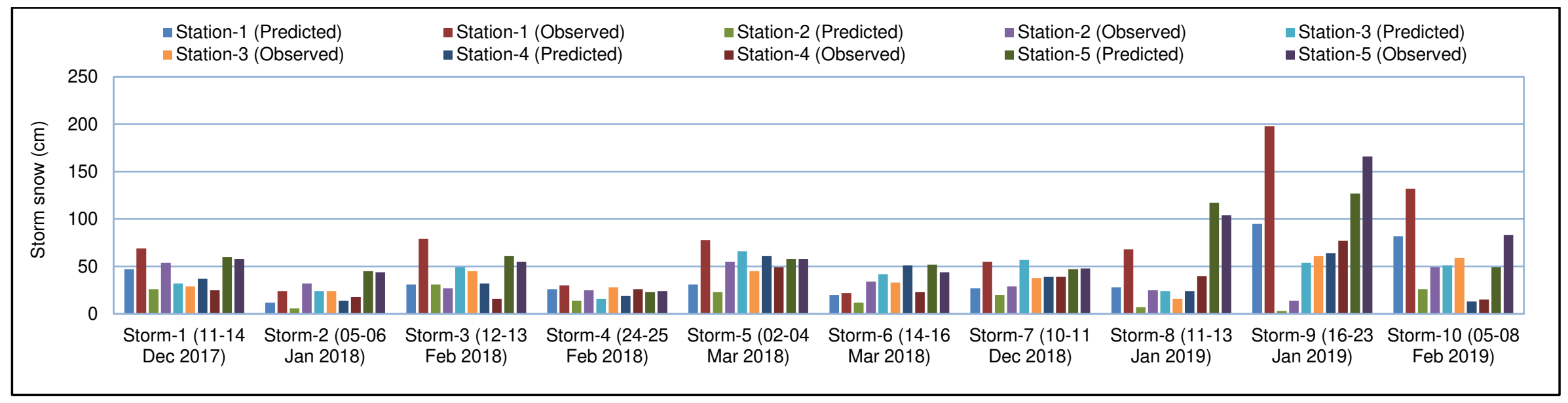

Fig 5: Observed and predicted storm snow during major snowfall events at five locations in Chowkibal-Tangdhar region of North-West Himalaya 

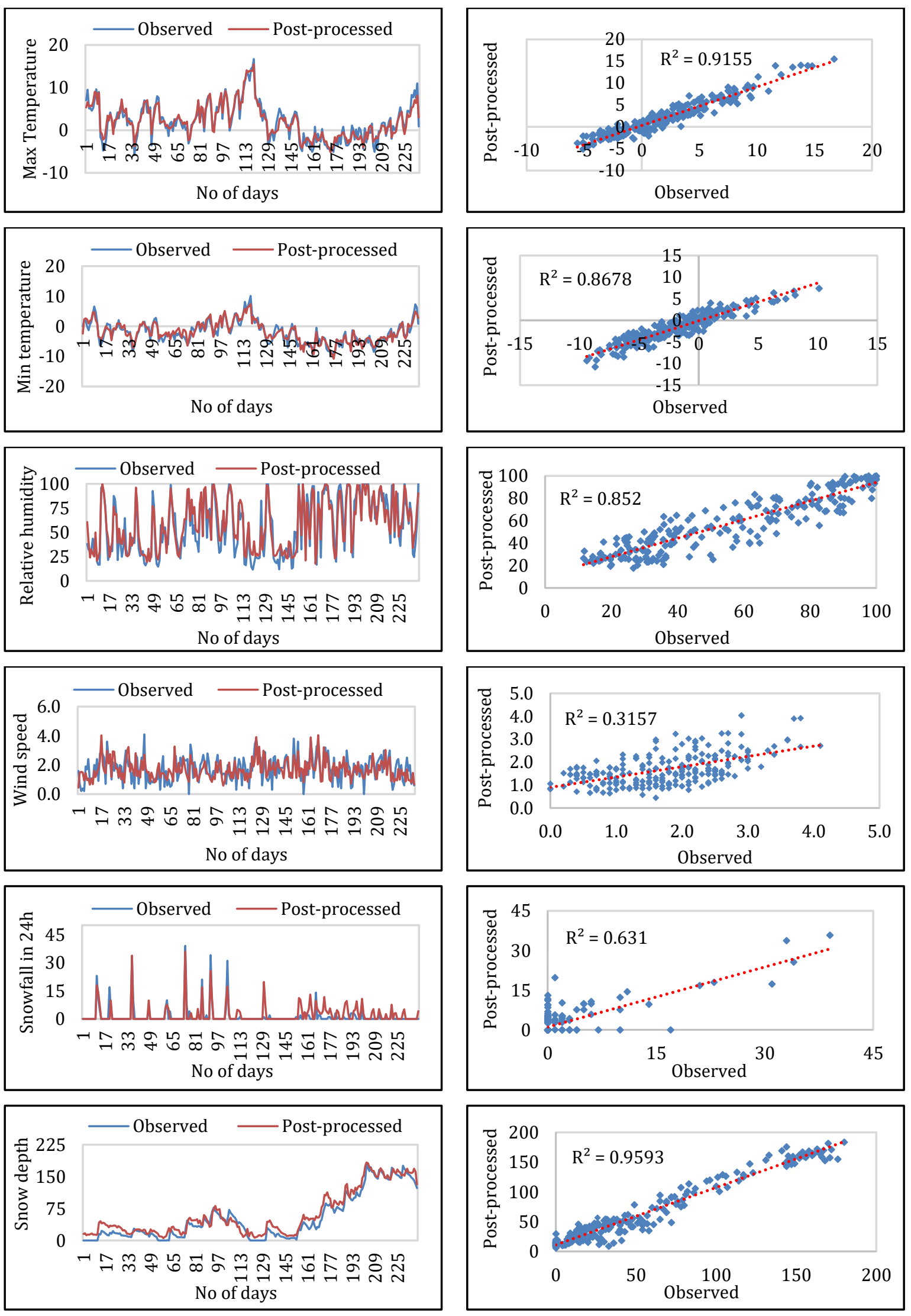

Fig 4: Comparison of spatially interpolated post-processed maximum temperature, minimum temperature, relative humidity, wind speed, snowfall in $24 \mathrm{~h}$ and snow depth with observed data of Station-3 in the C-T region. Line plots (left) and scatter plots (right) of observed and spatially interpolated post-processed data are shown for each variable. 
Table 1: Input variables used for post processing of WRF output variables

\begin{tabular}{|c|c|c|c|c|c|}
\hline $\begin{array}{l}\text { Maximum } \\
\text { temperature }\end{array}$ & $\begin{array}{l}\text { Minimum } \\
\text { temperature }\end{array}$ & Snow depth & $\begin{array}{l}\text { Relative } \\
\text { humidity }\end{array}$ & Wind Speed & Snowfall in $24 \mathrm{~h}$ \\
\hline $\begin{array}{l}\text { Maximum } \\
\text { temperature }\end{array}$ & $\begin{array}{l}\text { Maximum } \\
\text { temperature }\end{array}$ & $\begin{array}{l}\text { Maximum } \\
\text { temperature }\end{array}$ & $\begin{array}{l}\text { Maximum } \\
\text { temperature }\end{array}$ & $\begin{array}{l}\text { Maximum } \\
\text { temperature }\end{array}$ & $\begin{array}{l}\text { Maximum } \\
\text { temperature }\end{array}$ \\
\hline $\begin{array}{l}\text { Minimum } \\
\text { temperature }\end{array}$ & $\begin{array}{l}\text { Minimum } \\
\text { temperature }\end{array}$ & $\begin{array}{l}\text { Minimum } \\
\text { temperature }\end{array}$ & $\begin{array}{l}\text { Minimum } \\
\text { temperature }\end{array}$ & $\begin{array}{l}\text { Minimum } \\
\text { temperature }\end{array}$ & $\begin{array}{l}\text { Minimum } \\
\text { temperature }\end{array}$ \\
\hline $\begin{array}{l}\text { Ambient } \\
\text { temperature }\end{array}$ & $\begin{array}{l}\text { Ambient } \\
\text { temperature }\end{array}$ & $\begin{array}{l}\text { Ambient } \\
\text { temperature }\end{array}$ & $\begin{array}{l}\text { Ambient } \\
\text { temperature }\end{array}$ & $\begin{array}{l}\text { Ambient } \\
\text { temperature }\end{array}$ & $\begin{array}{l}\text { Ambient } \\
\text { temperature }\end{array}$ \\
\hline Relative humidity & Relative humidity & Relative humidity & Relative humidity & Relative humidity & Relative humidity \\
\hline Snowfall in $24 \mathrm{~h}$ & Snowfall in $24 \mathrm{~h}$ & Snowfall in $24 \mathrm{~h}$ & Snowfall in $24 \mathrm{~h}$ & Snowfall in $24 \mathrm{~h}$ & Snowfall in $24 \mathrm{~h}$ \\
\hline Snow depth & Snow depth & Snow depth & Snow depth & Snow depth & Snow depth \\
\hline Wind speed & Wind speed & Wind speed & Wind speed & Wind speed & Wind speed \\
\hline Sunshine hours & Sunshine hours & Sunshine hours & Sunshine hours & Sunshine hours & Sunshine hours \\
\hline $\begin{array}{l}\text { Maximum } \\
\text { temperature (WRF) }\end{array}$ & $\begin{array}{l}\text { Minimum } \\
\text { temperature (WRF) }\end{array}$ & Snow depth (WRF) & $\begin{array}{l}\text { Relative humidity } \\
\text { (WRF) }\end{array}$ & Wind speed (WRF) & $\begin{array}{l}\text { Snowfall in } 24 \mathrm{~h} \\
\text { (WRF) }\end{array}$ \\
\hline \multirow[t]{2}{*}{$\begin{array}{l}\text { Previous day } \\
\text { maximum } \\
\text { temperature }\end{array}$} & $\begin{array}{l}\text { Previous day } \\
\text { minimum } \\
\text { temperature }\end{array}$ & $\begin{array}{l}\text { Previous day snow } \\
\text { depth }\end{array}$ & $\begin{array}{l}\text { Previous day } \\
\text { Relative humidity }\end{array}$ & $\begin{array}{l}\text { Previous day wind } \\
\text { speed }\end{array}$ & $\begin{array}{l}\text { Previous day } \\
\text { snowfall in } 24 \mathrm{~h}\end{array}$ \\
\hline & & & $\begin{array}{l}\text { Atmospheric } \\
\text { pressure }\end{array}$ & & \\
\hline
\end{tabular}

Table 2: Lapse rate of temperature and adjustment factor for snowfall in $24 \mathrm{~h}$ and snow depth derived for C-T region of North-West Himalaya

\begin{tabular}{|c|c|c|c|}
\hline Months & Temperature & Snowfall in 24h & Snow depth \\
\hline December & $8.8^{\circ} \mathrm{C} / \mathrm{km}$ & $5 \mathrm{~cm} / \mathrm{km}$ & $30 \mathrm{~cm} / \mathrm{km}$ \\
\hline January & $8.2^{\circ} \mathrm{C} / \mathrm{km}$ & $11 \mathrm{~cm} / \mathrm{km}$ & $70 \mathrm{~cm} / \mathrm{km}$ \\
\hline February & $8.7^{\circ} \mathrm{C} / \mathrm{km}$ & $12 \mathrm{~cm} / \mathrm{km}$ & $80 \mathrm{~cm} / \mathrm{km}$ \\
\hline March & $8.6^{\circ} \mathrm{C} / \mathrm{km}$ & $4 \mathrm{~cm} / \mathrm{km}$ & $110 \mathrm{~cm} / \mathrm{km}$ \\
\hline
\end{tabular}


Table 3: Root mean square error and standard deviation of maximum temperature, minimum temperature, relative humidity, wind speed, snowfall in $24 \mathrm{~h}$ and standing snow generated for four AWS locations in Chowkibal-Tangdhar region of North-West Himalaya

\begin{tabular}{|l|c|c|c|c|c|c|c|c|c|c|}
\hline & \multicolumn{3}{|c|}{$\begin{array}{c}\text { Artificial Neural } \\
\text { network parameters }\end{array}$} & \multicolumn{3}{c|}{ Root mean square error and standard deviation of generated weather } \\
variables at AWS locations
\end{tabular}


Table 4: Root mean square error and standard deviation of maximum temperature, minimum temperature, relative humidity, wind speed, snowfall in $24 \mathrm{~h}$ and standing snow with and without post-processing of WRF output at five stations in Chowkibal-Tangdhar region of North-West Himalaya

\begin{tabular}{|c|c|c|c|c|c|c|}
\hline \multicolumn{7}{|c|}{ RMSE and SD of post-processed WRF variables } \\
\hline & & Station-1 & Station-2 & Station-3 & Station-4 & Station- 5 \\
\hline \multirow{3}{*}{$\begin{array}{l}\text { Maximum } \\
\text { temperature }\end{array}$} & RMSE (WRF) & 6.6 & 2.4 & 5.0 & 3.3 & 3.4 \\
\hline & RMSE (Post-processed WRF) & 1.9 & 1.5 & 1.4 & 1.61 & 1.6 \\
\hline & Standard deviation & 4.4 & 3.9 & 4.2 & 4.4 & 3.8 \\
\hline \multirow{3}{*}{$\begin{array}{l}\text { Minimum } \\
\text { temperature }\end{array}$} & RMSE (WRF) & 3.9 & 5.8 & 6.9 & 5.5 & 4 \\
\hline & RMSE (Post-processed WRF) & 1.2 & 1.4 & 1.4 & 1.5 & 1.45 \\
\hline & Standard deviation & 3.8 & 3.8 & 3.8 & 3.8 & 3.2 \\
\hline \multirow{3}{*}{ Relative humidity } & RMSE (WRF) & 38 & 22.4 & 16.2 & 21.3 & 21.6 \\
\hline & RMSE (Post-processed WRF) & 7.3 & 11.7 & 10.6 & 11.7 & 11.2 \\
\hline & Standard deviation & 13.4 & 29.2 & 27.7 & 31.6 & 28.8 \\
\hline \multirow{3}{*}{ Wind speed } & RMSE (WRF) & 1.6 & 2.2 & 3.5 & 3.1 & 3.4 \\
\hline & RMSE (Post-processed WRF) & 0.4 & 1.0 & 0.7 & 0.8 & 0.8 \\
\hline & Standard deviation & 0.7 & 1.4 & 0.9 & 0.8 & 1.0 \\
\hline \multirow{3}{*}{ Snowfall in $24 \mathrm{~h}$} & RMSE (WRF) & 7.5 & 5 & 4.1 & 3.8 & 6.4 \\
\hline & RMSE (Post-processed WRF) & 3.5 & 4.4 & 3.24 & 3.55 & 4.1 \\
\hline & Standard deviation & 8.3 & 5.4 & 4.5 & 4.2 & 4.9 \\
\hline \multirow{3}{*}{ Snow depth } & RMSE (WRF) & 97.4 & 54.2 & 60.4 & 30.7 & 168.9 \\
\hline & RMSE (Post-processed WRF) & 16 & 14.9 & 14.7 & 9.9 & 21 \\
\hline & Standard deviation & 69 & 35 & 48 & 28.1 & 98 \\
\hline
\end{tabular}


Table 5: Critical Success Index for different ranges of variables generated with 90m resolution for Station-3 in the C-T region of N-W Himalaya

\begin{tabular}{|l|l|l|l|l|l|l|l|l|l|l|l|}
\hline \multicolumn{2}{|l}{$\begin{array}{l}\text { Maximum } \\
\text { temperature }\end{array}$} & \multicolumn{2}{l|}{$\begin{array}{l}\text { Minimum } \\
\text { temperature }\end{array}$} & \multicolumn{2}{l|}{ Wind speed } & \multicolumn{2}{l|}{ Relative humidity } & \multicolumn{2}{l|}{ Snowfall in 24h } & \multicolumn{2}{l|}{ Snow depth } \\
\hline Ranges & CSI & Ranges & CSI & Ranges & CSI & Ranges & CSI & Ranges & CSI & Ranges & CSI \\
\hline$<=-6$ & 0.17 & $<=-10$ & 0.33 & 0 to 1 & 0.15 & $<=20$ & 0.03 & 0 to 5 & 0.94 & 0 to 30 & 0.69 \\
\hline-6 to -2 & 0.34 & -10 to -6 & 0.45 & 1 to 2 & 0.90 & 20 to 40 & 0.48 & 5 to 15 & 0.26 & 30 to 60 & 0.44 \\
\hline-2 to 2 & 0.50 & -6 to -2 & 0.47 & 2 to 3 & 0.18 & 40 to 60 & 0.30 & 15 to 25 & 0.09 & 60 to 90 & 0.31 \\
\hline 2 to 6 & 0.63 & -2 to 2 & 0.55 & 3 to 4 & 0.08 & 60 to 80 & 0.34 & 25 to 35 & 0.20 & 90 to 120 & 0.22 \\
\hline 6 to 10 & 0.76 & 2 to 6 & 0.38 & $>4$ & 0.00 & $>80$ & 0.71 & $>35$ & 0.33 & 120 to 150 & 0.24 \\
\hline 10 to 14 & 0.50 & 6 to 10 & 0.10 & & & & & & & $>150$ & 0.66 \\
\hline$>14$ & 0.25 & $>10$ & 0.00 & & & & & & & & \\
\hline
\end{tabular}

Table 6: Bias and NSE of variables generated with $90 \mathrm{~m}$ resolution for all five stations in the

\section{C-T region of N-W Himalaya}

\begin{tabular}{|c|c|c|c|c|c|c|c|c|c|c|}
\hline \multirow{2}{*}{$\begin{array}{l}\text { Variables } \\
\text { generated with } \\
90 \mathrm{~m} \text { resolution }\end{array}$} & \multicolumn{2}{|c|}{ Station-1 } & \multicolumn{2}{|c|}{ Station-2 } & \multicolumn{2}{|c|}{ Station-3 } & \multicolumn{2}{|c|}{ Station-4 } & \multicolumn{2}{|c|}{ Station-5 } \\
\hline & Bias & NSE & Bias & NSE & Bias & NSE & Bias & NSE & Bias & NSE \\
\hline $\begin{array}{l}\text { Maximum } \\
\text { temperature }\end{array}$ & 0.90 & 0.82 & 0.05 & 0.85 & 0.04 & 0.89 & -0.40 & 0.88 & 0.06 & 0.81 \\
\hline $\begin{array}{l}\text { Minimum } \\
\text { temperature }\end{array}$ & 0.16 & 0.89 & 0.24 & 0.84 & 0.11 & 0.85 & -0.44 & 0.83 & 0.01 & 0.84 \\
\hline Wind speed & 0.21 & -0.74 & 0.26 & 0.28 & -0.06 & 0.20 & 1.73 & 0.85 & -0.15 & 0.87 \\
\hline Relative humidity & 3.35 & 0.56 & -2.30 & 0.80 & 1.30 & 0.82 & -0.62 & 0.76 & -3.10 & 0.78 \\
\hline Snowfall in $24 \mathrm{~h}$ & -1.20 & 0.45 & -0.90 & 0.36 & 0.08 & 0.54 & 0.40 & 0.32 & 0.22 & 0.22 \\
\hline Snow depth & -12.4 & 0.96 & -0.10 & 0.78 & 10.0 & 0.92 & 0.30 & 0.90 & -0.10 & 0.96 \\
\hline
\end{tabular}

